\title{
Effect of nitrogen fertilization on the protein quality of timothy grass and silage
}

\author{
LIISA SYRJÄLÄ-QVIST ${ }^{1}$, EEVA PEKKARINEN ${ }^{1}$, JOUKO SETÄLÄ ${ }^{1}$ and \\ TAPANI KANGASMÄKI ${ }^{2}$ \\ I Department of Animal Husbandry, \\ ${ }^{2}$ Department of Plant Husbandry, University of Helsinki, SF-00710 Helsinki
}

\begin{abstract}
Timothy grass given $\mathrm{N}$ fertilizer at the rates of 40,80 and $120 \mathrm{~kg} \mathrm{~N} /$ ha was preserved in 3 glass-fibre silos of $0.4 \mathrm{~m}^{3}$.

The crude protein content of DM in the grass increased with the increase of $\mathrm{N}$ fertilization as follows: $\mathrm{N}_{40} 14.8 \%, \mathrm{~N}_{80} 18.4 \%$ and $\mathrm{N}_{120} 22.1 \%$, but the proportion of true protein in crude protein decreased: $\mathrm{N}_{40} 82 \%, \mathrm{~N}_{80} 78 \%$ and $\mathrm{N}_{120} 76 \%$. The proportion of watersoluble $\mathrm{N}$ in the total $\mathrm{N}$ in the grass was: $\mathrm{N}_{40} 27 \%, \mathrm{~N}_{80} 30 \%$ and $\mathrm{N}_{120} 33 \%$. The higher was the $\mathrm{N}$ fertilization level, the more rapidly was the protein of the grass degraded in the rumen. The amino acid profile of the protein was similar at all the $\mathrm{N}$ fertilization levels.

The quality of all the silages was good. The $\mathrm{NH}_{3}-\mathrm{N}$ fraction of total $\mathrm{N}$ was $2.8-3.9 \%$ and the proportion of water-soluble $\mathrm{N}$ in total $\mathrm{N}$ was $51-55 \%$. In silage $\mathrm{N}_{120}$ the decrease during ensiling in the proportion of true protein in crude protein and the increase in the proportion of water-soluble $\mathrm{N}$ in total $\mathrm{N}$ were smaller than in the other silages. The rumen degradability of protein during the first two hours was also lowest in this silage.
\end{abstract}

\section{Introduction}

The protein yields of swards can be increased either by using leguminous plants, e.g. red clover, or by increasing the nitrogen fertilization level of the grass. Little attention has been paid, however, to the quality and the feeding value of the protein in the herbage, when these methods are used. The purpose of this experiment was to study the effect of different nitrogen fertilization levels on the quality and the feeding value of the protein of timothy grass and the changes in its crude protein fraction during ensiling. Corresponding experiments concerning red clover have already been described (SYRJÄLÄQvist et al. 1984).

\section{Experimental procedures}

The timothy grass used for this experiment was from second-year sward. Basic nitrogen fertilizer was applied in spring at the rate of 
$100 \mathrm{~kg} \mathrm{~N} / \mathrm{ha}$. The first harvest was taken on 18 June and was used for the experiment described earlier (SyrJälä-Qvist et al. 1984). After the first cutting, the timothy sward was divided into three parts, which received nitrogen fertilizer at three different levels: 40 $\mathrm{kg}, 80 \mathrm{~kg}$ and $120 \mathrm{~kg} \mathrm{~N} / \mathrm{ha}$. The grass used for this experiment was from the second cutting. The harvesting date was 26 July, when the timothy was at the so-called silage stage, or when the ears of the timothy were near emergence or just formed.

Each silage, silage $1=\mathrm{N}_{40}$, silage $2=\mathrm{N}_{80}$ and silage $3=N_{120}$, was preserved in a glass-fibre silo of $0.4 \mathrm{~m}^{3}$. The grass was chopped and AIV II solution ( $80 \%$ formic acid and $2 \%$ orthophosphoric acid) was used as preservative, being applied as the silos were filled, at the rate of $5 \mathrm{l} / 1000 \mathrm{~kg}$ fresh grass. The sampling and analyses were as described earlier (SyrJäLÄ-Qvist et al. 1984).

\section{Results and discussion}

Silage raw materials

The dry matter and crude protein yields of the timothy at the different levels of nitrogen fertilizer application were as follows:

$\begin{array}{ccc}\text { Nitrogen kg/ha } & \text { Dry matter kg/ha } & \text { Protein } \mathrm{kg} / \mathrm{ha} \\ \mathrm{N}_{40} & 1927 & 285 \\ \mathrm{~N}_{80} & 2165 & 398 \\ \mathrm{~N}_{120} & 2023 & 447\end{array}$

Table 1. The chemical composition and the digestibility of the raw materials and the silages.

\begin{tabular}{|c|c|c|c|c|c|c|}
\hline \multirow[t]{2}{*}{ Nitrogen $\mathrm{kg} / \mathrm{ha}$} & \multicolumn{2}{|c|}{40} & \multicolumn{2}{|c|}{80} & \multicolumn{2}{|c|}{120} \\
\hline & Grass & Silage & Grass & Silace & Grass & Silage \\
\hline Dry matter, \% & 24.3 & 21.8 & 22.3 & 20.8 & 20.3 & 20.2 \\
\hline \multicolumn{7}{|l|}{$\%$ of dry matter: } \\
\hline Ash & 7.9 & 8.2 & 8.4 & 8.4 & 8.7 & 8.9 \\
\hline Crude protein & 14.8 & 15.2 & 18.4 & 18.3 & 22.1 & 22.2 \\
\hline Crude fat & 3.7 & 4.9 & 3.7 & 5.0 & 3.8 & 5.3 \\
\hline Crude fibre & 23.5 & 25.6 & 23.2 & 25.5 & 23.7 & 24.9 \\
\hline $\mathrm{N}$-free extract & 50.2 & 46.1 & 46.3 & 42.8 & 41.7 & 38.7 \\
\hline $\begin{array}{l}\text { In vitro digestibility } \\
\text { of organic matter, } \%\end{array}$ & 72.4 & 72.2 & 72.3 & 68.6 & 74.3 & 67.8 \\
\hline
\end{tabular}

Table 2. The criteria of the silage quality.

\begin{tabular}{|c|c|c|c|c|c|c|}
\hline \multirow[t]{2}{*}{ Nitrogen $\mathrm{kg} / \mathrm{ha}$} & \multicolumn{2}{|c|}{40} & \multicolumn{2}{|c|}{80} & \multicolumn{2}{|c|}{120} \\
\hline & Grass & Silage & Grass & Silage & Grass & Silage \\
\hline $\mathrm{pH}$ & & 4.01 & & 3.99 & & 3.98 \\
\hline \multicolumn{7}{|l|}{$\%$ of dry matter: } \\
\hline Acetic acid & & 1.51 & & 1.58 & & 2.89 \\
\hline Propionic acid & & + & & + & & - \\
\hline Butyric acid & & - & & - & & - \\
\hline Lactic acid & & 7.58 & & 6.79 & & 5.97 \\
\hline Sugars as glucose & 12.3 & 11.7 & 10.5 & 6.2 & 8.1 & 3.9 \\
\hline True protein & 12.1 & 8.1 & 14.1 & 10.3 & 16.9 & 12.3 \\
\hline $\begin{array}{l}\text { True protein, } \% \text { of crude } \\
\text { protein }\end{array}$ & 81.5 & 53.3 & 78.3 & 56.1 & 76.4 & 55.0 \\
\hline Soluble $\mathrm{N}, \%$ of total $\mathrm{N}$ & 27.1 & 54.2 & 29.6 & 54.7 & 33.4 & 50.5 \\
\hline $\mathrm{NH}_{3}-\mathrm{N}, \%$ of total $\mathrm{N}$ & & 2.8 & & 3.3 & & 3.9 \\
\hline
\end{tabular}


The increase in nitrogen fertilization clearly increased the crude protein content of dry matter, the values being 14.8, 18.4 and $22.1 \%$, respectively (Table 1). Although this increase was evident in the protein yields, the corresponding dry matter yields did not change very much.

The content of dry matter and water-soluble carbohydrates (sugars) decreased with the increase of nitrogen fertilization (Tables $1-2$ ), but the content of the other chemical constitutents was fairly similar in the different grasses. Corresponding results have been obtained in some other experiments (see e.g. McDonald 1981, Salo and Sormunen 1976).

In the other criteria describing the quality there were some differences between the grasses (Table 2, Figures 1-2). Although the proportion of true protein in crude protein was relatively high in all the samples, it decreased as the $\mathrm{N}$ fertilization level increased, as follows: $\mathrm{N}_{40} 82 \%, \mathrm{~N}_{80} 78 \%$ and $\mathrm{N}_{120}$

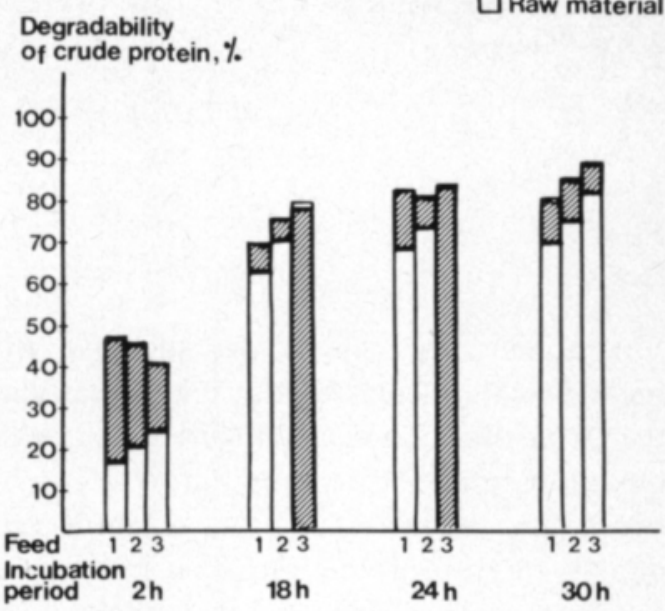

Fig. 1. The rumen degradability of the protein of the raw materials and the silages.

$76 \%$. The proportion of watersoluble nitrogen in total nitrogen increased with the increase in $\mathrm{N}$ fertilization, from 27 to 30 to $33 \%$.

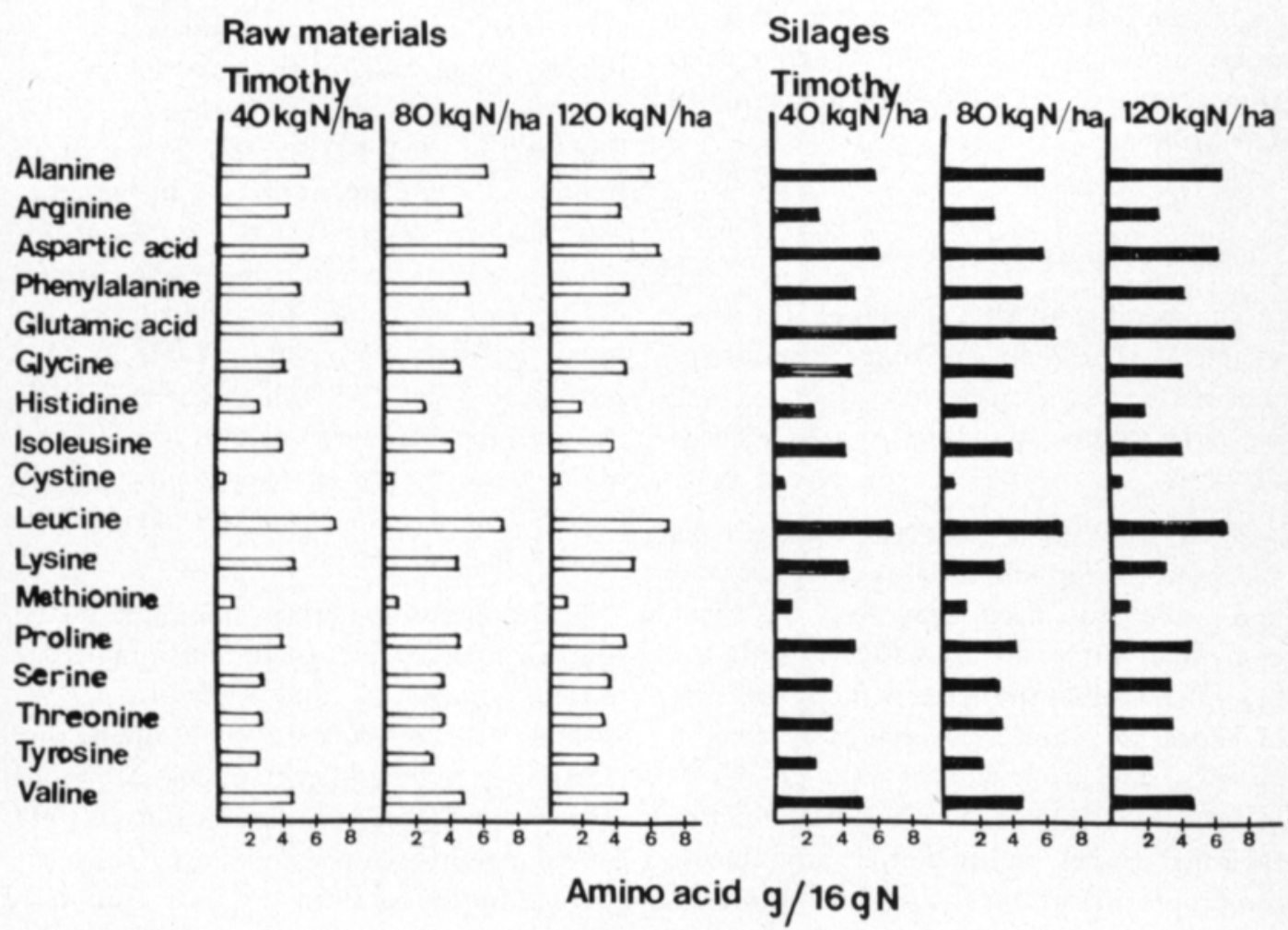

Fig. 2. The amino acid contents of the raw materials and the silages. 
The following percentage values were obtained for the degradability of crude protein in the rumen:

\begin{tabular}{lcccc} 
& \multicolumn{4}{c}{ Incubation period } \\
& $2 \mathrm{~h}$ & $18 \mathrm{~h}$ & $24 \mathrm{~h}$ & $30 \mathrm{~h}$ \\
$\mathrm{~N}_{40}$ & 17 & 63 & 69 & 70 \\
$\mathrm{~N}_{80}$ & 21 & 71 & 73 & 76 \\
$\mathrm{~N}_{120}$ & 24 & 79 & 84 & 82
\end{tabular}

Although the rumen degradability of crude protein increased with the increase in the $\mathrm{N}$ fertilization level (Figure 1), it was quite low in all the samples during the first two hours. An increase in the rumen degradability of grass protein with an increasing $\mathrm{N}$ fertilization level has also been noted in another experiment (Møller 1981 ref. SetÄLÄ 1983).

The $\mathrm{N}$ fertilization did not affect the amino acid composition of the crude protein of timothy grass, which was similar to that in grasses in other studies (ANDERSEN 1980, SALo et al. 1982). Mo (1977) and ANDERSEN (1980) observed that nitrogen fertilization had some effect on the free amino acids of grass, especially aspartic and glutamic acid, whose content increased with increasing $\mathrm{N}$ fertilization.

\section{Changes during ensiling}

The quality of all the silages was good (Table 2). The chemical composition of the dry matter of the silages corresponded well with the composition in the raw material (Table 1).

There were slight differences between the silages in the fermentation of carbohydrates and crude protein. In silage $\mathrm{N}_{40}$, the sugar content of the grass decreased by only 0.6 $\%$-units, whereas the corresponding decrease in silages $\mathrm{N}_{80}$ and $\mathrm{N}_{120}$ was more than 4 $\%$-units. The proportion of water-soluble $\mathrm{N}$ in total $\mathrm{N}$ was lower in silage $\mathrm{N}_{120}$ than in the other silages. In some other experiments the proportion of water-soluble $\mathrm{N}$ increased as the nitrogen fertilization level increased
(Ettala et al. 1974), Poutiainen and Rinne 1976).

The rumen degradability of crude protein was higher in the silages than in the corresponding grasses, especially during the first two hours of incubation (Figure 1). These results confirm the earlier findings (SYRJÄLÄQvist et al. 1984) that the higher is the proportion of true protein in crude protein and the lower the proportion of watersoluble $\mathrm{N}$ in total silage $\mathrm{N}$, the slower is the degradation of crude protein in the rumen. The increase of the ammonia- $\mathrm{N}$ fraction of total $\mathrm{N}$ in silage has also been found to be reflected in increased degradation of protein in the rumen (SETÄLÄ 1983). In this experiment the proportion of ammonia-N was rather low and similar in all the silages $(3-4 \%)$, so that its effect on the rumen degradability of protein is difficult to evaluate. $\mathrm{N}$ fertilization seemed to increase also the level of degradation of crude protein in silage (Figure 1). The amino acid profile of protein did not change very much during ensiling (Figure 2).

The total amount of inorganic substances in timothy increased with the rising level of $\mathrm{N}$ fertilization (Table 1). As the $\mathrm{N}$ fertilization level of timothy rose, the content of all the minerals that were analysed increased at least slightly, except that of Ca. As no effluent was formed in the silages, the changes during ensiling in the contents of the different minerals were small (Table 3). According to VARIS (1983), high $\mathrm{N}$ fertilization increases the total amounts of $\mathrm{K}, \mathrm{Ca}, \mathrm{Na}$ and $\mathrm{Mg}$ in grass, but the changes in the amounts mainly depend on the availability of the minerals in the soil.

The total ensiling losses amounted to the following percentages of the fresh material: silage $\mathrm{N}_{40} 8.2 \%, \mathrm{~N}_{80} 8.8 \%$ and $\mathrm{N}_{120} 4.1 \%$. Although the dry matter content of the raw materials was no higher than 20-24\%, no effluent was formed. The ensiling losses were caused mainly by surface spoilage, which accounted for the following losses of fresh material: $\mathrm{N}_{40} 7.8 \%, \mathrm{~N}_{80} 8.5 \%$ and $\mathrm{N}_{120} 3.5 \%$. 
Table 3. The inorganic constituents of the raw materials and the silages.

\begin{tabular}{|c|c|c|c|c|c|c|}
\hline \multirow[t]{2}{*}{ Nitrogen kg/ha } & \multicolumn{2}{|c|}{40} & \multicolumn{2}{|c|}{80} & \multicolumn{2}{|c|}{120} \\
\hline & Grass & Silage & Grass & Silage & Grass & Silage \\
\hline $\mathrm{Ca} \mathrm{g} / \mathrm{kg} \mathrm{Dm}$ & 5.0 & 5.4 & 4.8 & 4.9 & 4.7 & 4.9 \\
\hline$"$ & 2.6 & 2.9 & 2.9 & 3.2 & 2.9 & 3.2 \\
\hline $\mathrm{Mg}$ & 1.3 & 1.4 & 1.4 & 1.5 & 1.6 & 1.6 \\
\hline$"$ & 26.2 & 28.0 & 30.6 & 31.9 & 31.4 & 34.2 \\
\hline $\mathrm{Na} \mathrm{mg/kg} \mathrm{DM}$ & 170 & 110 & 170 & 110 & 200 & 120 \\
\hline $\mathrm{Fe}$ & 101 & 107 & 102 & 113 & 123 & 141 \\
\hline Mn & 34 & 37 & 45 & 46 & 48 & 52 \\
\hline $\mathrm{Zn}$ & 39 & 40 & 49 & 49 & 53 & 54 \\
\hline $\mathrm{Cu}$ & 8 & 7 & 9 & 8 & 9 & 8 \\
\hline
\end{tabular}

The fermentation losses made up a very small proportion of total losses. The losses of the different nutrients mainly paralleled the total ensiling losses of the different silages (Table 4).

The palatability to sheep was good in all the silages, the average daily voluntary intake being $2.6-2.7 \mathrm{~kg} \mathrm{DM} / 100 \mathrm{~kg}$ liveweight. In the grass the in vitro digestibility of organic matter was little higher at fertilization level $\mathrm{N}_{120}$ than at the other levels. Conversely, in the silages the in vitro digestibility of organic matter decreased with increasing $\mathrm{N}$ fertilization level (Table 1). In an earlier experiment the in vitro digestibility of
Table 4. The ensiling losses, $\%$ of the ensiled amounts.

\begin{tabular}{lrrr}
\hline Nitrogen $\mathrm{kg} / \mathrm{ha}$ & 40 & 80 & 120 \\
\hline Total & 8.2 & 8.8 & 4.1 \\
Dry matter & 16.0 & 13.1 & 2.5 \\
Organic matter & 16.3 & 13.1 & 2.7 \\
Ash & 12.2 & 13.3 & -0.1 \\
Crude protein & 13.5 & 13.6 & 2.2 \\
Crude fat & -11.5 & -17.6 & -34.9 \\
Crude fibre & 8.4 & 4.4 & -2.4 \\
Sugars as glucose & 19.8 & 49.3 & 53.0 \\
\hline
\end{tabular}

organic matter decreased slightly with increasing $\mathrm{N}$ fertilization level in both silage and its raw material (SALO 1978).

\section{References}

ANDERSEN C.E. 1980. Dyrkningsfaktorerens indflydelse på planteres indhold af organiske og uorganiske kvaelstofforbindelser. Dyrkningfaktorer og planternes kemiske sammansaetning. København. 261 p.

Ettala E., Takala M. \& Lampila M. 1974. Typpilannoitustasot lypsylehmien säilörehuruokinnassa. Kehittyvă Maatalous 18: 51-59.

McDonald P. 1981. The Biochemistry of Silage. Chichester, John Wiley and sons Ltd. 261 p.

Mo M. 1977. Studies on protein quality of gass silage. Quality of forage. Lantbrukshögskolan, Inst. för husdjurens utfodring och vård, Rapport 54: 79-90.

Møler P.D. 1981. Personal communication. Ref. SETÁLA J. 1983.

Poutiainen E. \& Rinne K. 1976. Typpilannoituksen vaikutus săilörehun ravintoarvoon. Kehittyvă Maatalous 29: 14-21.

SALO M.-L. 1978. Kasvuasteen ja typpilannoituksen vaikutus säilörehunurmen rehuarvoon. Kehittyvă Maatalous 38: 3-9.

SAlo M.-L. \& Sormunen R. 1976. Nurmisäilörehukokeita maatilasiiloissa. 1. Rehuarvon muutokset ja sảilöntătappiot. J. Sci. Agric. Soc. Finl. 48: 109-127.

Salo M.-L., TUORI M. \& KiISKInen T. 1982. Rehutaulukot ja ruokintanormit. 70 p. Helsinki 1982.

SEtÃLÁ J. 1983. Lypsylehmien valkuaisen tarve ja sen ruokinnalle asettamat vaatimukset. Lypsylehmien 
ruokinnan ja rehuntuotannon talous. Työtehoseuran julkaisuja no. 252: 5-60.

Syrjālā-Qvist l., Pekkarinen E., Setālá J. \& Kangas MĀKı T. 1984. Effect of red clover/timothy ratio on the feeding value of protein and the quality of silage. J. Sci. Agrig. Soc. Finl. Vol. 56: 193-198.

\section{SELOSTUS}

\section{Typpilannoitustason vaikutus timotein ja siitä valmistetun säilörehun valkuaisen \\ laatuun}

\section{Liisa Syrjälä-Qvist ${ }^{1}$, Eeva Pekkarinen ${ }^{1}$, Jouko Setälä ${ }^{1}$ ja Tapani Kangasmäki ${ }^{2}$}

I Kotieläintieteen laitos, ${ }^{2}$ Kasvinviljelytieteen laitos, Helsingin yliopisto, 00710 Helsinki 71

Vertailtavana oli timotein kolme $\mathrm{N}$ lannoitustasoa: 40, 80 ja $120 \mathrm{~kg} \mathrm{~N} /$ ha. Näistä valmistettiin săilörehut $0.4 \mathrm{~m}^{3}: \mathrm{n}$ lasikuitusiiloihin.

Typpilannoitustason noustessa timoteiruohon kuivaaineen raakavalkuaispitoisuus nousi seuraavasti: $\mathrm{N}_{40}$ $14.8 \%, \mathrm{~N}_{80} 18.4 \%$ ja $\mathrm{N}_{120} 22.1 \%$. Raakavalkuaissato oli eri $\mathrm{N}$ lannoitustasoilla $\mathrm{N}_{40} 285, \mathrm{~N}_{80} 398$ ja $\mathrm{N}_{120} 447$ $\mathrm{kg} /$ ha ja kuiva-ainesato vastaavasti $\mathrm{N}_{40} 1927, \mathrm{~N}_{80} 2165$ ja $\mathrm{N}_{120} 2023 \mathrm{~kg} / \mathrm{ha}$.

Typpilannoitustason noustessa puhdasvalkuaisen osuus raakavalkuaisesta laski timoteiruohossa seuraavasti: $\mathrm{N}_{40} 82 \%, \mathrm{~N}_{80} 78 \%$ ja $\mathrm{N}_{120} 76 \%$ ja vastaavasti
VARIS E. 1983. Typpi kasvien sadon ja măărăn săătelijảnă. Maataloustieteen păivăt. Suomen maat. tiet. seuran tiedote 3: 16-20.

Ms received July 10, 1984 liukoisen typen osuus kokonaistypestă nousi, $\mathrm{N}_{40}$ $27 \%, \mathrm{~N}_{80} 30 \%$ ja $\mathrm{N}_{120} 33 \%$. Myős timotein valkuaisen pötsihajoavuus lisäăntyi timotein typpilannoitustason noustessa. Valkuaisen aminohappokoostumuksessa ei năillă typpilannoitustasoilla ollut eroja.

Säilörehut olivat laadultaan hyviă. Rehujen $\mathrm{pH}$ oli $\leq 4$, ammoniumtypen osuus oli $2.8-3.9 \%$ ja liukoisen typen osuus $51-55 \%$ kokonaistypestả. Säilönnän aikana puhdasvalkuaisen osuus raakavalkuaisesta laski ja liukoisen typen osuus kokonaistypestă nousi vähiten $\mathrm{N}_{120}$ săilörehussa. Myös valkuaisen pötsihajoavuus oli 2 ensimmäisen tunnin aikana matalin tăssä rehussa. 